
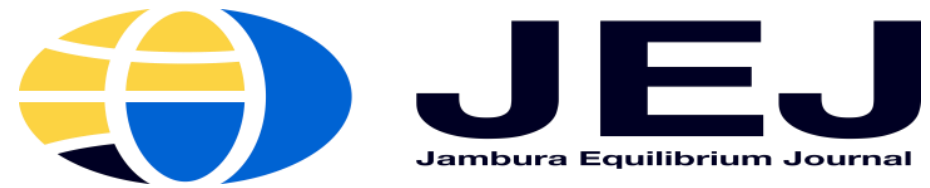

Volume 3. Issue 2. 2021

P-ISSN 2655-9110

E-ISSN 2656-0445

http://ejurnal.ung.ac.id/index.php/equij

\title{
The Effect of Corruption, Democracy and Foreign Debt on Economic Growth in Asian Pacific Countries
}

\author{
Rommy Fernando Putra ${ }^{1}$, Dewi Zaini Putri ${ }^{2}$ \\ Faculty of Economics, Universitas Negeri Padang ${ }^{1,2}$
}

\begin{abstract}
Economic growth can be defined as a process of changing the economic conditions of a country on an ongoing basis towards a better condition during a certain period. This study aims to examine the effect of corruption, democracy and external debt on economic growth in 7 countries Asia Pasific. This is because of The Asia Pacific became known around the 1980s when financial market, international trade and political condition have increased. The data used is panel data during the period 2014-2018, and collected by data documentation and library obtained from World Bank, International Transparency and Freedom In The World. Using the panel data regression, the estimation results are (1) Corruption has a positive and significant effect on economic growth in 7 Asia Pacific countries, with a regression coefficient value of -0.2753 , (2) Democracy has a positive and significant effect on economic growth in 7 Asia Pacific countries with a regression coefficient value of 0.0586, (3) External debt has a significant positive effect on economic growth in 7 countries Asia Pacific region with a regression coefficient of 0.7604 (4) Corruption, Democracy and External Debt have a significant effect on economic growth in 7 countries in the Asia Pacific region, with a probability value ( $F$-statistic) of $0.0008<\alpha=0.05$.
\end{abstract}

Keywords: Corruption; Democracy; External Debt; Economic Growth; Panel Data Regression

\section{INTRODUCTION}

Economic growth can be defined as a process of changing the economic conditions of a country on an ongoing basis towards a better condition during a certain period. The Asia Pacific became known around the 1980s when financial market, international trade and political condition have increased. According to the IMF's, the Asia Pacific region continues to show strong growth over rising protectionism, a rapidly aging population and slow productivity growth. The economic prospects for the Asia and Pacific region predict that these region's growth will increase in 2017 compared to the previous year. Economic growth in Asia Pacific will remain strong in 2018, as the region continues to be a global growth leader (Fokus Negara IMF, 2017).

Based on the latest analysis from the World Bank, entitled The East Asia and Pacific Economic Updates, it expressed optimism and a positive projection of the economic growth in the Asia Pacific region. Renewal of the global economy and expansion of global trade is good news for 
the Asia Pacific region which has always succeeded in restoring the living conditions of its people. For countries in the Asia Pacific region, the challenge that must be faced is balancing between short-term economic growth goals and reducing vulnerability for the short and long term so that this region can achieve inclusive and sustainable growth (Mediaindonesia.com, 2017).

Corruption occurs because of the weak legislative and judicial system. Corruption is one of a factor affecting economic growth of a country. Several studies have examined the factors influence economic growth, one of which is corruption . Alfada (2019) states that corruption has a negative effect on economic growth. The harmful effects of corruption will be stronger when there is an interaction between corruption and government investment spending. Because when there is corruption in government investment spending, it will cause the government spending to be less than the maximum because part of the budget has been taken by parties who want to benefit themselves which will reduce the country's economic growth rate. Mo (2001) stated that corruption has a negative effect on economic growth in 54 countries. Each 1\% increase in the level of corruption reduces the rate of economic growth by $0.72 \%$ or in other words, a one-unit increase in the corruption index reduces the growth rate by 0.545 percentage points. However, Lui (1985) shows that corruption can increase economic growth. This is because of corrupt bureaucrats can use the money from corruption for businessc, so it expand the economy. From the corruption perception index data in 7 Asia Pacific countries from 2014-2018 is experiencing increase while the rate of economic growth also increased.

Fuad (2007) democratization can increase economic growth and stability in a country. Democracy is a system in which there is recognition of the rights of minorities. Thus, if a minority wants to carry out business activities, their rights will be protected by law. If these entrepreneurs feel safe and comfortable in carrying out business activities, of course, in the future economic growth and stability will also improve.

According to Grundler and Krieger (2016) in a study entitled "Democracy and Growth" states that there is a positive relationship between democracy and economic growth. Democracy has an effect on growth in countries with higher investment. Democratic countries have a higher educated population, a higher share of investment, and a higher fertility rate. However, if seen from the data when the Democracy Index in 7 Asia Pacific countries from 2014-2018 has increased, rate of economic growth from 2014-2018 has decreased.

Foreign debt is also one of the factors affecting the economic growth of a country. External debt is a portion of a country's total debt obtained from creditors outside that country. Recipients of foreign debts can be governments, companies or individuals. The form of debt can be in the form of money obtained from private banks, governments of other countries or international financial institutions such as the IMF and World Bank (Ulfa, 2017).

Junaedi (2018) states that foreign debt can have a positive impact on economic growth by increasing productivity, increasing employment opportunities and restoring the balance of payments. However, if debt is used inappropriately, it is possible that the debt will have a negative impact on economic growth and even threaten the country's macroeconomic stability. However, if you look at the data on external debt in 7 Asia Pacific countries from 2014-2018, it shows positive and increasing trends, while the rate of economic growth has decreased. 
Based on the this problem, the objective of this research is to determine the extent of the influence of corruption, democracy and foreign debt on economic growth in 7 countries in the Asia Pacific region.

\section{METHODOLOGY}

The data used in this study are secondary data, namely corruption, foreign debt, democracy and economic growth, sourced from the World Bank, International Transparency and Freedom In The World from 2014-2018. Corruption is measured in a unit score, Democracy is measured in index units, External Debt is measured in million US Dollars and economic growth is measured in terms of growth rates in percent.

The method used is the panel regression method which has 3 models, namely the Common Effect Model (CEM), Fixed Effect Model (FEM), and Random Effect Model (REM) which are selected through 3 model selection tests namely Chow Test, Hausman Test, and Langrange Test. Multiplier.

In the Chow test is used to choose between choosing between CEM or FEM (prob.> $0.05=\mathrm{CEM}$ ), while the Hausman is used to choose between FEM or REM (prob.> $0.05=\mathrm{REM}$ ) and the last LM Testis used to choose between REM or CEM (prob. $>0.05=$ CEM). If the Hausman Test has selected the FEM, then there is no need to proceed to the LM test and continue to the Classical Assumption Test.

In this panel regression analysis the model used is as follows:

$Y_{i t}=\beta_{0}+\beta_{1} X_{1 i t}+\beta_{2} X_{2 i t}+$ $\beta_{3} \log X_{3 i t}+U_{i t}$

Where Yit is Economic Growth, $\mathrm{X} 1$ it is Corruption, $\mathrm{X} 2 \mathrm{it}$ is Democracy, $\mathrm{X} 3 \mathrm{it}$ is External Debt, $\beta 0$ is a constant if $X=0$, $\beta$ is the regression coefficient and $U$ it is the Error term.

\section{RESULTS AND DISCUSSION}

\section{Results}

\section{Panel Data Regression Analysis}

Panel data regression analysis is used to examine the effect of independent variables on dependent variables in the combined form of time and place series data. From the research results, it can be determined the magnitude of the influence of corruption (X1), democracy (X2) and foreign debt $(\mathrm{X} 3)$ on economic growth $(\mathrm{Y})$ in 7 Asia Pacific countries. Data testing begins with a model selection test to determine the right model to use. Based on Table below, the selected model is the Common Effect Model (CEM) with the following estimation results.

The panel regression equation is obtained as follows:

$Y=11.5622-0.2753 X 1+0.0586 X 2+$

$0.7604 L X 3$

Based on the estimation results, partially all variables have a significant effect on economic growth, namely corruption (X1), democracy (X2) and foreign debt with significant values 0.0004 , 0.0012 and 0.0094 respectively. While simultaneously seen from the probability (F-statistic), it have a significant effect on the economy with a significant value of 0.0008 which is smaller than alpha 0.05. variable corruption (X1) has a positive effect on economic growth with a regression coefficient of -0.2753 . This means that every decrease in the corruption perception index will increase economic growth by $0.2753 \%$ and vice versa. Democracy (X2) has a positive effect on economic growth with a regression coefficient of 0.0586 . This means that for every increase in the democracy index, economic growth will increase by $0.0586 \%$ and vice versa. While External debt (X3) has a positive effect on economic growth 
with a regression coefficient of 0.7604 . This means that an increase in foreign debt, economic growth will increase by $0.7604 \%$ and vice versa.

Table 1 Common Effect Model (CEM) Estimation Results

Dependent Variable: Y

Method: Panel Least Squares

Date: 02/19/20 Time: 11:25

Sample: 20142018

Periods included: 5

Cross-sections included: 7

Total panel (balanced) observations: 35

\begin{tabular}{lrlll}
\hline \hline \multicolumn{1}{c}{ Variable } & Coefficient & Std. Error & t-Statistic & Prob. \\
\hline \hline \multicolumn{1}{c}{ C } & 2.759082 & 3.026969 & 0.911500 & 0.3691 \\
X1 & -0.275372 & 0.069341 & -3.971270 & 0.0004 \\
X2 & 0.058691 & 0.016456 & 3.566574 & 0.0012 \\
LX3 & 0.760436 & 0.274738 & 2.767860 & 0.0094 \\
\hline \hline R-squared & 0.411947 & Mean dependent var & 5.233143 \\
Adjusted R-squared & 0.355039 & S.D. dependent var & 1.900427 \\
S.E. of regression & 1.526223 & Akaike info criterion & 3.790679 \\
Sum squared resid & 72.21002 & Schwarz criterion & 3.968433 \\
Log likelihood & -62.33689 & Hannan-Quinn criter. & 3.852040 \\
F-statistic & 7.238788 & Durbin-Watson stat & 1.031723 \\
Prob(F-statistic) & 0.000811 & & & \\
\hline \hline
\end{tabular}

Source: Data processed, 2020

\section{Discussion}

\section{The Effect of Corruption on Economic Growth in Asia Pacific}

Based on the results of data analysis and hypothesis testing conducted in this study, corruption has a significant positive effect on economic growth in 7 countries in the Asia Pacific region. This means that when corruption increases, as seen from the decrease in the corruption perception index score, it will increase a country's economic growth. An increase in economic growth due to an increase in corruption in a country can occur, because corruption can make it easier for someone to do business. For example, it is difficult for someone to establish a project by the owner of the power, then by paying an additional fee in the form of such as bribe will make it easier to set up the project.

This is in line with the research found by Lui (1985), it shows that corruption has a positive effect on economic growth due to corrupt bureaucrats can use the money from corruption by making business matters easier by giving bribes, which in turn will increase economic growth. Even so, corruption is still not good because corruption only thinks about personal interests through the abuse of power. The government must eradicate corruption because later corruption can harm the state. Efforts that can be done are strengthening 
weak bureaucratic institutions, or imposing heavy sanctions on perpetrators of corruption in a country. That way, it will reduce the level of corruption in the country.

\section{The Effect of Democracy on Economic Growth in Asia Pacific}

Based on the estimation results, democracy has a significant and positive effect on economic growth in 7 countries in the Asia Pacific region. This means that when democracy in a country increases, it will increase economic growth in that country. This shows that when democracy in a country gets better, it will increase the country's economic growth. In theory, increasing the democracy index in a country will also increase the country's economic growth. In line with the estimation results of this study, based on research found by Mesquite (2001) that democracy has a positive effect on economic growth in the country. He found that, in democratic countries, economic growth increases with the change of power. Economic growth depends on sound economic policies, but good economic policies are not always in the interests of political leaders. With a democratic system in a country, society can replace the power of bad political leaders so that it will have an impact on increasing economic growth.

\section{The Effect of External Debt on Economic Growth in Asia Pacific}

Based on the results of data analysis in this study, foreign debt has a significant and positive effect on economic growth in 7 countries in the Asia Pacific region. External debt is used by borrowing countries which is usually used to finance infrastructure. So, foreign debt that does not exceed the threshold will have an influence in increasing the country's economic growth. The better the use of foreign debt, the better the economic growth will be towards balance. External debt is a portion of the total debt of a country obtained from creditors outside the country. In theory, an increase in foreign debt in a country will also increase the country's economic growth. In line with the estimation results of this study, based on research found by Rachmadi (2013), foreign debt has a positive effect on economic growth. Economic sectors that absorb quite high foreign debt are proven to increase the economic growth.

\section{CONCLUSION}

Based on the results of the Panel Model Regression Analysis using the Common Effect Model can be drawn conclusion as follows:

1. Corruption has a positive and significant effect on economic growth in 7 Asia Pacific countries, with a regression coefficient value of -0.2753 .

2. Democracy has a positive and significant effect on economic growth in 7 Asia Pacific countries with a regression coefficient value of 0.0586 ,

3. External debt has a significant positive effect on economic growth in 7 countries Asia Pacific region with a regression coefficient of 0.7604 .

4. Corruption, Democracy and External Debt have a significant effect on economic growth in 7 countries in the Asia Pacific region, with a probability value (F-statistic) of $0.0008<\alpha=0.05$

\section{REFERENCES}

Alfada, A. (2019). The Destructive Effect of Corruption on Economic Growth in Indonesia: A Threshold Model. Heliyon.

Fokus Negara IMF. (2017). Ekonomi Asia yang Dinamis Terus Memimpin 
Pertumbuhan Global. Penilaian Kawasan IMF.

Fuad, F. (2007). Hukum, Demokrasi dan Pembangunan Ekonomi. Lex Jurnalica, Vol.5 No.1.

Grundler, K., \& Krieger, T. (2016). Democracy and Growth: Evidence from a machine learning indicator. European Journal of Political Economy.

Junaedi, D. (2018). Hubungan Antara Utang Luar Negeri Dengan Perekonomian dan Kemiskinan: Komparasi Antarezin Pemerintah. Simposium Nasional Keuangan Negara.

Kompasiana.com. (2019, Mei 31). Dampak Utang Luar Negeri bagi Perekonomian Suatu Negara. Retrieved Maret 2, 2020, from https://www.kompasiana.com/widy anur/5cf0b44e18ffee 48 bf000ec $3 /$ da mpak-utang-luar-negeri-bagiperekonomian-suatu-negara

Lui, F. T. (1985). An Equilibrium Queuing Model of Bribery. Journal of Political Economy, 760-781.

Machmud, A. (2016). Perekonomian Indonesia: Pasca Reformasi. Jakarta: Erlangga.

Mediaindonesia.com. (2017, October 9). Perekonomian Asia-Pasifik semakin Menjanjikan. Retrieved January 20, 2020, from https://mediaindonesia.com/read/de tail/126235-perekonomian-asiapasifik-semakin-menjanjikan

Mesquita, B. B., Morrow, J. D., Siverson, R., \& Alastair, S. (2001). Political Competition and Economic Growth. Journal of Democracy, 58-72.

Mo, P. H. (2001). Corruption and Economic Growth. Journal of Comparative Economics, 66-79.

Rachmadi, A. L. (2013). Analisis Pengaruh Utang Luar Negeri
Terhadap Pertumbuhan Ekonomi di Indonesia Tahun 2001-2011. Jurnal Ilmiah Mahasiswa FEB. Republika.co.id. (2015, Maret 2). Korupsi Bisa Meninggkatkan Pertumbuhan Ekonomi? Retrieved Maret 12, 2020, from https://www.republika.co.id/berita/ nasional/hukum/15/03/02/nkktiakorupsi-bisa-meningkatkanpertumbuhan-ekonomi

Republika.co.id. (2015, Maret 2). Korupsi Bisa Meningkatkan Pertumbuhan Ekonomi? Retrieved Maret 2, 2020, from https://www.republika.co.id/berita/ nasional/hukum/15/03/02/nkktiakorupsi-bisa-meningkatkanpertumbuhan-ekonomi

Semma, M. (2008). Negara dan Korupsi: Pemikiran Moctar Lubis atas Negara, Manusia Indonesia dan Perilaku Politik. Jakarta: Yayasan Obor Indonesia.

Sulisworo, D. (2012). Demokrasi. Hibah Materi Pembelajaran Non Konvensional.

Todaro, M. P. (2011). Pembangunan Ekonomi Edisi Kesebelas Jilid 1. Jakarta: Erlangga. 